\author{
Bartosz BRZOZOWSKI ${ }^{1}$ \\ Przemysław KORDOWSKI ${ }^{2}$ \\ Zdzisław ROCHALA ${ }^{3}$ \\ Konrad WOJTOWICZ ${ }^{4}$
}

\title{
SYSTEM ANTYKOLIZYJNY Z WIZUALIZACJA OTOCZENIA DLA BSP
}

\begin{abstract}
Wykonywanie bezpiecznych lotów wewnątrz pomieszczeń przez bezpilotowy statek powietrzny (BSP) wymaga zastosowania odpowiednich czujników umożliwiających wykrywanie przeszkód. W Zakładzie Awioniki i Uzbrojenia Lotniczego jest projektowany system antykolizyjny wykorzystujący laserowy skaner przestrzeni jako źródło informacji o otoczeniu BSP. Wprowadzenie w ruch obrotowy czujnika URG-04LX firmy Hokuyo wykonującego pomiary w jednej płaszczyźnie pozwala na uzyskanie trójwymiarowej chmury punktów obrazujących obiekty wokół BSP. Otrzymane w ten sposób dane, dzięki zastosowaniu odpowiednich algorytmów, pozwalają na określenie obszarów niebezpiecznych dla lotu, wyznaczenie trajektorii oraz wizualizację otoczenia statku powietrznego. Ruch obrotowy skanera jest tak wykonywany, że środkowa laserowa wiązka pomiarowa, niezależnie od kąta obrotu czujnika, jest zawsze skierowana zgodnie z wektorem ruchu statku powietrznego. Takie rozwiązanie zapewnia ciągły pomiar odległości oraz zagęszczenie chmury punktów przed BSP.
\end{abstract}

Słowa kluczowe: bezzałogowy statek powietrzny, system antykolizyjny, wizualizacja otoczenia

\section{Wprowadzenie}

Bezpieczeństwo wykonywania lotów przez BSP jest jednym z najistotniejszych zagadnień rozważanych podczas projektowania systemów autonomicznych. W przypadku statków powietrznych przeznaczonych do wykonywania zadań na otwartej przestrzeni największy nacisk jest kładziony na rozwiązania awaryjnego lądowania, natomiast problem zderzenia z przeszkodą jest często

\footnotetext{
1 Autor do korespondencji/corresponding author: Bartosz Brzozowski, Wojskowa Akademia Techniczna, ul. S. Kaliskiego 2, 00-908 Warszawa, tel. (22) 6839851, e-mail: bbrzozowski @wat.edu.pl

${ }^{2}$ Przemysław Kordowski, przemekkordowski@gmail.com

${ }^{3}$ Zdzisław Rochala, zrochala@wat.edu.pl

${ }^{4}$ Konrad Wojtowicz, kwojtowicz@wat.edu.pl
} 
pomijany. Dzieje się tak, gdyż wysokość lotu, na której jest przeprowadzana misja, jest dobierana w okolicach $100 \mathrm{~m}$ nad powierzchnią ziemi. Wówczas przekracza ona warstwę koron drzew, ale znajduje się poniżej minimalnej dopuszczalnej wysokości lotu dla samolotów i śmigłowców załogowych. W ten sposób ogranicza się prawdopodobieństwo kolizji z innym statkiem powietrznym i przeszkodami stacjonarnymi. Aby całkowicie wyeliminować zagrożenie, są projektowane czujniki wykrywające obiekty oraz są prowadzone badania mające na celu opracowanie algorytmów ich omijania [1-4]. Loty w terenie zurbanizowanym i wewnątrz pomieszczeń są możliwe wyłącznie w przypadku posiadania wiarygodnych informacji o otoczeniu BSP. Podczas sterowania ręcznego stosuje się kamery przekazujące w czasie rzeczywistym obraz do operatora. Dzięki temu możliwe jest sterowanie w trybie FPV (ang. First-person view), w którym pilot widzi obszar przed statkiem powietrznym i na bieżąco wybiera bezpieczną trajektorię lotu. Z kolei systemy autonomiczne wymagają określenia obszarów dozwolonych i zabronionych do wykonywania lotu i na tej podstawie zaimplementowane algorytmy wyznaczają trasę omijającą przeszkody. Do ich wykrywania obecnie najczęściej są stosowane systemy optyczne [1-3]. Urządzenie opracowane w Zakładzie Awioniki i Uzbrojenia Lotniczego Wojskowej Akademii Technicznej jest przeznaczone dla bezpilotowych statków powietrznych pionowego startu i lądowania klasy mini, wykonujących misje wewnątrz pomieszczeń $[5,6]$.

\section{Budowa i zasada działania systemu}

Zaprojektowany system antykolizyjny jest oparty na laserowym skanerze przestrzeni URG-04LX firmy Hokuyo (rys. 1.). Jest to czujnik optyczny emitujący spójną wiązkę promieniowania podczerwonego długości fali $785 \mathrm{~nm}$, modulowanej częstotliwościami 46,55 MHz oraz 53,2 MHz. Pomiar odległości jest dokonywany na podstawie różnicy faz sygnału nadawanego i odbieranego. Zasięg skanera nie przekracza $5 \mathrm{~m}$, a dokładność wynosi $\pm 2 \%$ zmierzonej odległości. W celu wykonania pomiaru w płaszczyźnie zastosowano zwierciadła obracane z użyciem silnika ze stałą prędkością $600 \mathrm{obr} / \mathrm{min}$. Oznacza to, że pojedynczy pomiar dla całej płaszczyzny jest wykonywany w ciągu $100 \mathrm{~ms}$, a zastosowana częstotliwość wysyłania pojedynczych impulsów pozwala na otrzymanie rozdzielczości ok. 0,36 stopnia. Konstrukcja urządzenia ogranicza efektywny kąt dokonywania pomiarów do 240 stopni [7].

$\mathrm{Na}$ potrzeby opracowania skanera trójwymiarowego zdecydowano się ograniczyć kąt pomiarowy czujnika do 120 stopni. Wynikało to z przyjętego założenia, że projektowane urządzenie ma analizować przestrzeń znajdującą się przed BSP. Wprowadzone ograniczenie nie miało wpływu na czas wykonywania pomiarów, ale dwukrotnie zmniejszyło liczbę przetwarzanych danych w stosunku do nastaw maksymalnych. Ponadto na podstawie przeprowadzonych analiz i badań stwierdzono, że wystarczającą rozdzielczością na potrzeby systemu an- 
tykolizyjnego jest 1 stopień. Ponieważ rozdzielczość czujnika jest ponadtrzykrotnie większa, postanowiono, że trzy kolejne pomierzone wartości odległości będą uśredniane. Pozwoliło to na kolejne zredukowanie liczby danych. W celu uzyskania trójwymiarowej chmury punktów czujnik URG-04LX wprowadzono w ruch obrotowy. Został on umieszczony na podstawie wykonanej ze stopu aluminium, którą przymocowano do serwomechanizmu modelarskiego o wysokim momencie obrotowym i zakresie ruchu 180 stopni. Czujnik umieszczono względem serwomechanizmu tak, że lustro pomiarowe znajduje się dokładnie w osi obrotu jego układu wykonawczego. Oś obrotu pokrywa się ze środkowym (sześćdziesiątym) stopniem pomiarowym czujnika i jest skierowana równolegle do osi podłużnej statku powietrznego. Rozwiązanie to umożliwia ciągły pomiar odległości przed BSP, niezależnie od położenia serwomechanizmu skanera, a punkty pomiarowe tworzą na płaszczyźnie współśrodkowe okręgi (rys. 2.). Otrzymane dane pomiarowe są przesyłane do komputera pokładowego.

Rys. 1. Czujnik URG-04LX firmy Hokuyo

Fig. 1. A Hokuyo URG-04LX sensor

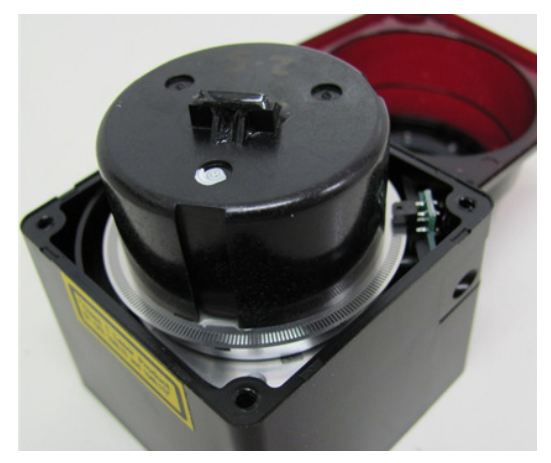

Rys. 2. Zasada działania skanera trójwymiarowego

Fig. 2. Principle of operation of the three-dimensional scanner

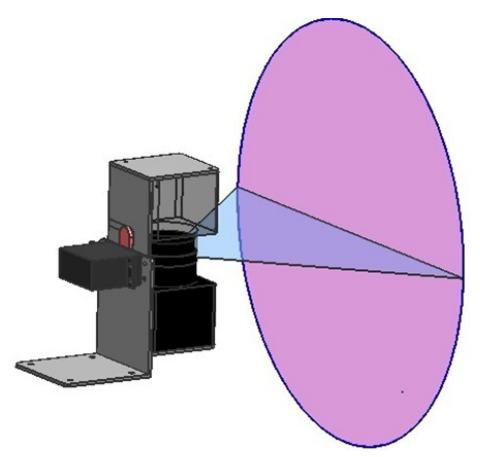

Komputer pokładowy stanowi jednostkę nadrzędną odpowiedzialną za prawidłowe działanie całego systemu awionicznego. W tym wypadku jednym z zadań jest zarządzanie trójwymiarowym skanerem przestrzeni i przetwarzanie otrzymanych od niego danych pomiarowych. Komunikacja odbywa się w zależności od konfiguracji za pośrednictwem interfejsu RS232, SPI lub I2C. Do 
obsługi czujnika i serwomechanizmu zastosowano 8-bitowy mikrokontroler AT90USB firmy Atmel (rys. 3.). Czujnik jest urządzeniem klasy USB CDC (ang. Universal Serial Bus Communications Device Class), z którym komunikacja po zainstalowaniu odpowiednich sterowników odbywa się tak samo, jak w standardzie RS-232. Po konfiguracji i inicjalizacji czujnika mikrokontroler wysyła polecenie wykonania pomiaru po każdej zmianie pozycji serwomechanizmu. Kąt skoku serwomechanizmu jest ustalany przed rozpoczęciem pomiarów w zakresie od 1 do 9 stopni, co determinuje szerokość zmiany sygnału sterującego PWM (ang. Pulse Width Modulation) w każdym kroku. Po wykonaniu przez serwomechanizm obrotu o 180 stopni punkty pomiarowe są wysyłane z mikrokontrolera do komputera pokładowego w postaci dwóch kątów i odległości. Pierwsza wartość kąta jest zawarta w przedziale \pm 60 stopni i określa odchylenie wiązki pomiarowej z położenia środkowego, druga z kolei determinuje położenie serwomechanizmu. W komputerze pokładowym zaimplementowano algorytmy transformujące pozyskane dane do prostokątnego układu współrzędnych, umożliwiając ich wykorzystanie do wyznaczenia obszarów niebezpiecznych lub wizualizację po przesłaniu do stacji naziemnej.

Wizualizacja danych reprezentujących otoczenie BSP może być zrealizowana z wykorzystaniem kilku niezależnych programów. Pierwszym jest opracowana aplikacja do obsługi trójwymiarowego skanera. Umożliwia ona zaprezentowanie punktów pomiarowych na płaszczyźnie $X Y$ z uwzględnieniem odległości reprezentowanej poprzez zmianę barwy punktu (rys. 4.). Kolor ustala się w formacie RGB (ang. Red, Green, Blue), podając trzy zmienne całkowite w zakresie od 0 do 255, odpowiadające kolejno barwom: czerwonej, zielonej i niebieskiej. Zobrazowanie przedstawia punkty od 0 do $5000 \mathrm{~mm}$. Dla punktów w zakresie od 0 do 2500 wartość barwy czerwonej jest ustalana proporcjonalnie do wartości współrzędnej $Z$, wartość barwy zielonej jest stała i równa 255, wartość barwy niebieskiej wynosi 0. Dla punktów w zakresie od 2500 do 5000 wartość barwy czerwonej jest stała i równa 255, wartość barwy zielonej jest ustalana proporcjonalnie do wartości współrzędnej $Z$, a wartość barwy niebieskiej wynosi 0. Uzyskane $\mathrm{w}$ ten sposób zobrazowanie przedstawia odległość w zakresie barw od zielonej, przez żółtą, do czerwonej. Zaprojektowana w ten sposób aplikacja pozwala na automatyczną wizualizację każdego pomiaru, jednak posiada znaczne ograniczenia funkcjonalne. Przede wszystkim nie daje możliwości zobrazowania całego pomieszczenia, a jedynie jedną z jego ścian. Do zastosowań, w których niezbędna była wizualizacja perspektywy lub trójwymiarowy model otoczenia, korzystano z ogólnodostępnych programów, takich jak MeshLab czy CloudCompare, przeznaczonych do pracy na wczytanych z pliku danych o przestrzeniach trójwymiarowych. Ostatnim rozwiązaniem, z którego korzystano, była biblioteka PCL (ang. Point Cloud Library) przeznaczona do implementacji algorytmów przetwarzania chmury punktów pomiarowych we własnych aplikacjach. 


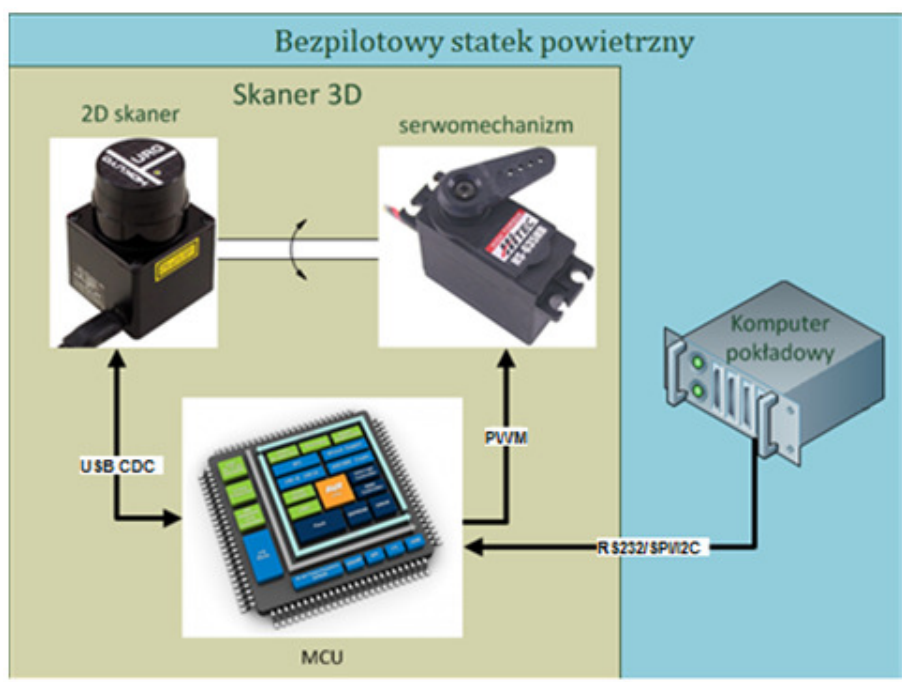

Rys. 3. Schemat funkcjonalny skanera 3D

Fig. 3. Functional diagram of the 3D scanner

Rys. 4. Zestawienie skanowanego obszaru i jego cyfrowej wizualizacji

Fig. 4. Illustration of registration of the scanned area and its digital visualisation

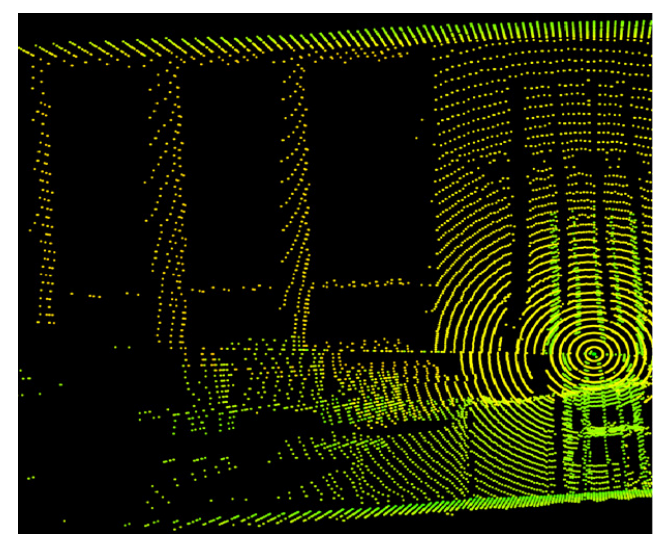

Algorytm wykrywania przeszkód oparto na dostępnych w bibliotece PCL funkcjach analizujących wzajemne położenie punktu skanowania oraz wyników pomiarów. Na ich podstawie określono punkty niebezpieczne (rys. 5.), czyli takie, które znajdowały się najbliżej czujnika i jednocześnie najdalej od płaszczyzny tła. Wizualizacja tych punktów została przygotowana wyłącznie na potrzeby weryfikacji poprawności działania zastosowanych algorytmów. W systemie antykolizyjnym wyznaczenie obszarów niebezpiecznych odbywa się w komputerze pokładowym, a informacje o ich położeniu należy uwzględnić w algorytmach wyznaczania trajektorii lotu i systemach sterowania automatycznego. 


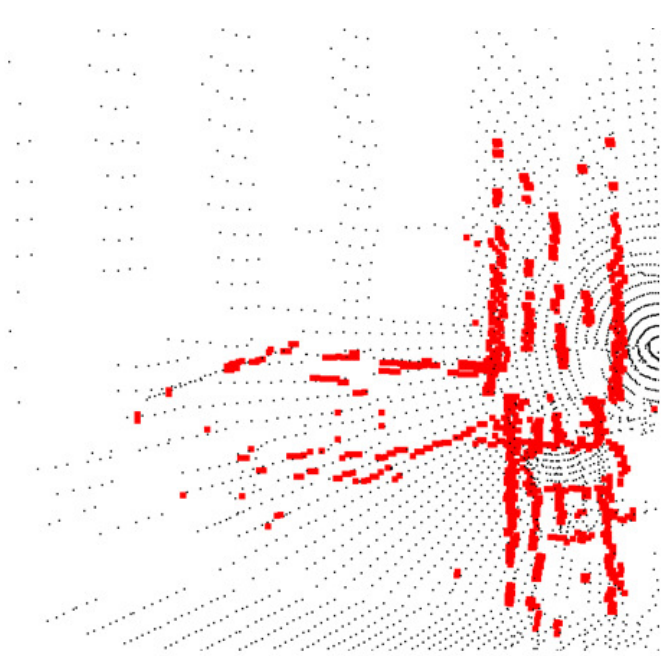

Rys. 5. Wyznaczone punkty niebezpieczne

Fig. 5. Determined dangerous points

\section{Podsumowanie}

Zaprojektowany w Zakładzie Awioniki i Uzbrojenia Lotniczego system antykolizyjny jest kompaktowym rozwiązaniem przeznaczonym dla BSP klasy mini, który ma możliwość zawisu w zadanym położeniu. Podczas badań weryfikacyjnych stwierdzono, że pomimo stosowania sprawdzonych i poprawnie działających algorytmów korekcji położenia czujnika otrzymywano wyniki znacznie bardziej zbliżone do rzeczywistych, gdy czujnik się nie poruszał. Ponadto skanowanie $\mathrm{w}$ zawisie jest niezbędne $\mathrm{w}$ przypadku wykonywania pomiarów przy maksymalnej rozdzielczość, gdyż całkowity czas skanowania przestrzeni wynosi blisko $40 \mathrm{~s}$. Rekomendowany krok pomiarowy serwomechanizmu wynosi 5 stopni, gdyż czas pełnego pomiaru skraca się do niecałych $8 \mathrm{~s}$, a system jest jeszcze w stanie wykryć pionowe pręty o średnicy $10 \mathrm{~mm}$ znajdujące się w odległości $1 \mathrm{~m}$ od skanera (rys. 5.). Ponadto otoczenie może zostać zwizualizowane $\mathrm{z}$ akceptowalną dokładnością. Dalsze zwiększanie kroku pomiarowego skutkuje znacznym zawężeniem efektywnego kąta pomiarowego, co oznacza, że wiarygodne wyniki otrzymuje się jedynie dla kilkunastu środkowych stopni. Przeprowadzone testy laboratoryjne, nieuwzględniające poprawek położenia przestrzennego czujnika, mogły spowodować brak pełnej zgodności wizualizacji w stosunku do rzeczywistego kształtu obiektów, jednakże nie miało to znaczącego wpływu na poprawność działania algorytmu wykrywania punktów niebezpiecznych. Dalsza rozbudowa systemu uwzględnia integrację przyspieszeniomierzy i giroskopów z podstawą skanera trójwymiarowego w celu wprowadzenia dokładniejszej poprawki jej położenia przestrzennego. Ponadto jest planowana zmiana czujnika na urządzenie o większej rozdzielczości i prędkości skanowania. 


\title{
Literatura
}

[1] Brockherde W.: Flying 3D eye-bots. Research News, 05/2012, Fraunhofer-Gesellschaft, May 2012, Topic 4.

[2] Fasano G., Accardo D., Moccia A., Carbone C., Ciniglio U., Corraro F., Luongo S.: Multi-sensor based fully autonomous non-cooperative collision aviodance system for unmanned air vehicles. J. Aerospace Computing, Information and communication, October 2008, 338.

[3] Khvilivitzky A.: Visual collision avoidance system for unmanned aerial vehicles. United States Patent no 5, 581, 250, 1996.

[4] Su-Cheol H., Hyochoong B.: Proportional navigation-based optimal collision avoidance for UAVs. $2^{\text {nd }}$ Int. Conf. Autonomous Robots and Agents, Palmerston North, New Zealand 2004, 76-81.

[5] Brzozowski B.: Projekt wyposażenia bezpilotowego statku powietrznego zwiększającego bezpieczeństwo lotu. 7. Sesja Naukowa Mechanika Stosowana, Bydgoszcz 2012, 10-11.

[6] Brzozowski B.: Design concepts of an UAV proximity module using laser range scanner. Adv. Chem. Mech. Eng., I/II (2012), 33-38.

[7] Kawata H., Ohya A., Yuta S., Santosh W., Mori T.: Developement of ultra-small lightweight optical range sensor system. Int. Conf. Intelligent Robots and Systems (IROS'05), Edmonton 2005, 1078-1083.

\section{ANTI-COLLISION SYSTEM WITH SURROUNDING VISUALISATION FOR UAV}

\begin{abstract}
A bstract
To perform safe indoor flights by an unmanned aerial vehicle (UAV) it is necessary to use suitable sensors in order to detect obstacles. In the Department of Avionics and Air Armament an anti-collision system is being developed, which uses laser range scanner as an information source about surrounding of the UAV. Rotating the Hokuyo URG-04LX sensor which conducts measurements in one plane allows to obtain three dimensional point cloud of objects around the UAV. With data obtained in that way, after applying suitable algorithms, areas dangerous for flight can be determined, trajectory computed and surrounding visualised. Scanner's rotational movement is performed in such a way that the middle laser measurement beam, regardless sensors rotation angle, always point in a direction parallel to heading vector of the UAV. This method guarantees continuous distance measurement and concentration of points cloud in front of the UAV.
\end{abstract}

Keywords: unmanned aerial vehicle, anti-collision system, surrounding visualization

DOI: $10.7862 / \mathrm{rm} .2013 .36$

Otrzymano/received: $15.09 .2013 \mathrm{r}$.

Zaakceptowano/accepted: $22.11 .2013 \mathrm{r}$. 